\title{
1-(2',5'-Dihydroxyphenyl)-3-(2-fluoro-4-hydroxyphenyl)-1-
}

\section{propanone (RGM079): A positive allosteric modulator of $\alpha 7$ nicotinic receptors with analgesic and neuroprotective activity}

María Jesús Pérez de Vega, ${ }^{*, a}$ Cristina Fernandez-Mendivil, ${ }^{\text {b }}$ Roberto de la Torre, ${ }^{\mathrm{c}}$ Sara González-Rodríguez, ${ }^{\mathrm{c}}$ José Mullet, ${ }^{\mathrm{d}}$ Francisco Sala, ${ }^{\mathrm{d}}$ Salvador Sala, ${ }^{\mathrm{d}}$ Manuel Criado, Silvia Moreno-Fernández, ${ }^{\mathrm{e}}$ Marta Miguel, ${ }^{\mathrm{e}}$ Asia Fernández-Carvajal, ${ }^{\mathrm{c}}$ Antonio FerrerMontiel, ${ }^{\mathrm{c}}$ Manuela G. López, ${ }^{\mathrm{b}}$ Rosario González-Muñiz ${ }^{*, a}$

anstituto de Química Médica, IQM-CSIC, Juan de la Cierva 3, 28006 Madrid, Spain

b Instituto Teófilo Hernando, Department of Pharmacology, Universidad Autónoma de Madrid, Arzobispo Morcillo 4, 28029 Madrid, Spain.

'Instituto de Investigación, Desarrollo e Innovación en Biotecnología Sanitaria de Elche (IDiBE), Universidad Miguel Hernández, Avenida de la Universidad s/n, 03202 Elche (Alicante), Spain ${ }^{d}$ Instituto de Neurociencias, Universidad Miguel Hernández-CSIC, 03050 Sant Joan d'Alacant, Spain eInstituto de Investigación en Ciencias de la Alimentación (CSIC-UAM), C/ Nicolás Cabrera 9, 28049 Madrid, Spain

2. Figure S1. Coincubation experiment with OA in SH-Y5S5 cells. 


\section{METHODS ADME-TOX STUDY}

\subsection{ADME-Tox: Solution Properties}

\subsubsection{Aqueous solubility}

Aqueous solubility $(\mu \mathrm{M})$ was determined by comparing the peak area of the principal peak in a calibration standard $(200 \mu \mathrm{M})$ containing organic solvent (methanol/water, $60 / 40, v / v)$ with the peak area of the corresponding peak in a buffer sample. In addition, chromatographic purity $(\%)$ was defined as the peak area of the principal peak relative to the total integrated peak area in the HPLC chromatogram of the calibration standard. A chromatogram of the calibration standard of each test compound, along with a UV/VIS spectrum with labeled absorbance maxima, was generated.

\subsubsection{Protein binding}

The peak areas of the test compound in the buffer and test samples were used to calculate percent binding and recovery according to the following formulas:

$$
\begin{aligned}
& \text { Protein binding }(\%)=\left[\left(\text { Area }_{\mathrm{p}}-\text { Area }_{\mathrm{b}}\right) / \text { Area }_{\mathrm{p}}\right]^{*} 100 \\
& \text { Recovery }(\%)=\left[\left(\text { Area }_{\mathrm{p}}+\text { Area }_{\mathrm{b}}\right) / \text { Area }_{\mathrm{c}}\right]^{*} 100
\end{aligned}
$$

Where:

Area $_{p}=$ Peak area of analyte in protein matrix

Area $=$ Peak area of analyte in buffer

Area $_{c}=$ Peak area of analyte in control sample

\subsection{ADME-Tox: In vitro absorption}

\subsubsection{Permeability}

The apparent permeability coefficient $\left(\mathrm{P}_{\mathrm{app}}\right)$ of the test compound was calculated as follows: 


$$
\mathrm{P}_{\text {app }}(\mathrm{cm} / \mathrm{s})=\left[\mathrm{V}_{\mathrm{R}} * \mathrm{C}_{\mathrm{R}, \text { end }} / \Delta \mathrm{t}\right] *\left[1 / \mathrm{A} *\left(\mathrm{C}_{\mathrm{D}, \text { mid }}-\mathrm{C}_{\mathrm{R}, \mathrm{mid}}\right)\right]
$$

where $V_{R}$ is the volume of the receiver chamber. $C_{R \text {,end }}$ is the concentration of the test compound in the receiver chamber at the end time point, $\Delta \mathrm{t}$ is the incubation time and $\mathrm{A}$ is the surface area of the cell monolayer. $\mathrm{C}_{\mathrm{D} \text {,mid }}$ is the calculated mid-point concentration of the test compound in the donor side, which is the mean value of the donor concentration at time 0 minute and the donor concentration at the end time point. $\mathrm{C}_{\mathrm{R} \text {,mid }}$ is the mid-point concentration of the test compound in the receiver side, which is one half of the receiver concentration at the end time point. Concentrations of the test compound were expressed as peak areas of the test compound.

\subsubsection{Recovery of the test compound from the permeability assay}

The recovery of the test compound was calculated as follows:

$$
\text { Recovery }(\%)=\left[\left(\mathrm{V}_{\mathrm{D}} * \mathrm{C}_{\mathrm{D} \text {,end }}+\mathrm{V}_{\mathrm{R}} * \mathrm{C}_{\mathrm{R}, \text { end }}\right) / \mathrm{V}_{\mathrm{D}} * \mathrm{C}_{\mathrm{D} 0}\right]^{* 100}
$$

where $V_{D}$ and $V_{R}$ are the volumes of the donor and receiver chambers, respectively. $C_{D \text {,end }}$ is the concentration of the test compound in the donor sample at the end time point. $C_{R \text {,end }}$ is the concentration of the test compound in the receiver sample at the end time point. $\mathrm{C}_{\mathrm{D} 0}$ is the concentration of the test compound in the donor sample at time zero. Concentrations of the test compound are expressed as peak areas of the test compound.

\subsubsection{Fluorescein assessment for permeability assays}

Fluorescein was used as the cell monolayer integrity marker. Fluorescein permeability assessment (in the A-B direction at $\mathrm{pH} 7.4$ on both sides) was performed after the permeability assay for the test compound. The cell monolayer that had a fluorescein permeability of less than $1.5 \times 10^{-6} \mathrm{~cm} / \mathrm{s}$ for Caco-2 and MDR1-MDCKII cells and $2.5 \mathrm{x}$ $10-6 \mathrm{~cm} / \mathrm{s}$ for MDCKII cells was considered intact, and the permeability result of the test compound from intact cell monolayer is reported. 


\subsection{ADME-Tox: In vitro metabolism}

1.3.1 Intrinsic clearance (microsomes, S9, cryopreserved hepatocytes, recombinant CYP, recombinant UGT)

Metabolic stability, expressed as percent of the parent compound remaining, was calculated by comparing the peak area of the compound at the time point relative to that at time-0. The half-life $\left(\mathrm{T}_{1 / 2}\right)$ was estimated from the slope of the initial linear range of the logarithmic curve of compound remaining (\%) vs. time, assuming the first-order kinetics. The apparent intrinsic clearance $\left(\mathrm{CL}_{\mathrm{int}}\right.$, in $\mu \mathrm{L} / \mathrm{min} / \mathrm{pmol}, \mu \mathrm{L} / \mathrm{min} / \mathrm{mg}$ or $\mu \mathrm{L} / \mathrm{min} /$ Mcell) was calculated according to the following formula:

$\mathrm{CL}_{\text {int }}=0.693 / \mathrm{T}_{1 / 2} *(\mathrm{mg}$ protein $/ \mu \mathrm{L}$ or million cells $/ \mu \mathrm{L}$ or pmol CYP isoyme $/ \mu \mathrm{L})$ 


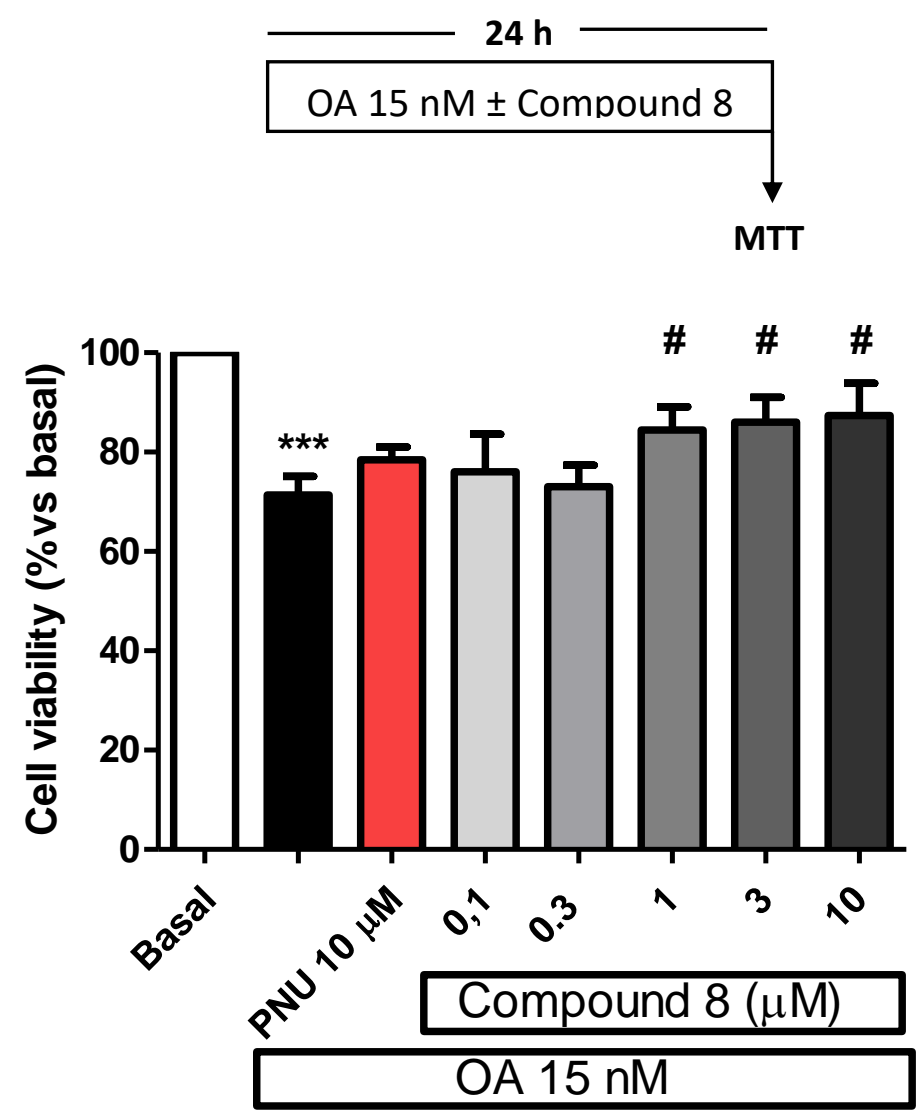

Figure S1. Figure S1. Compound 8 caused neuroprotection in the human neuroblastoma cell line when co-incubated with the toxic AO. (A) The protocol used: Compound 8 was coincubated with $A O(15 \mathrm{nM})$ for $24 \mathrm{~h}$ and cell viability measured by the MTT method. (B) Effect of increasing concentrations of compound 8 against OA ( $15 \mathrm{nM})$ induced-toxicity SH-S5Y5 cells. As positive control, the $\alpha 7$ agonist PNU-282987 (10 mM) was used. Data represent the mean \pm SEM of 6 different experiments. ${ }^{* * *} \mathrm{p}<0.001$ compared to basal; ${ }^{\#}<<0.05$ compared to OA; ${ }^{\# \#} \mathrm{p}<0.01$ compared to $\mathrm{OA}$; ${ }^{\# \#} \mathrm{p}<0.001$ compared to OA. 